\title{
Penerapan Model Pembelajaran Berbasis Masalah Berbantuan Media Power Point untuk Meningkatkan Aktivitas dan Hasil Belajar Siswa SDN Pandean Lamper 02 Semarang
}

\author{
Novita Arum Mandasari \\ Program Studi Pendidikan Profesi Guru, FKIP, Universitas PGRI Semarang \\ Corresponding Author. Email: novitta.arum.na@gmail.com
}

\begin{abstract}
The purpose of this study was to increase student activity and learning outcomes using a problem-based learning model assisted by power point media for third grade students at SDN Pandean Lamper 02 Semarang. The research method used is classroom action research consisting of 3 cycles with 4 stages, namely planning, action, observation, and reflection. The subjects of this study were third grade students with a total of 30 people. The data collection techniques used were observation, interviews, tests, and documentation, while the data analysis techniques used descriptive analysis. The results showed that the average percentage of student activity classically increased. In the pre-cycle before treatment it was $65 \%$, in the first cycle it was $70 \%$, in the second cycle it was $74 \%$ while in the third cycle it was $87 \%$. While the percentage of mastery learning outcomes in the pre-cycle is $37 \%$, in the first cycle it is $57 \%$, in the second cycle it is $73 \%$, while in the third cycle it is $90 \%$. Based on the results of the research that has been done, it can be concluded that learning in Theme 8 using a problem-based learning model assisted by power point media can improve student activities and learning outcomes.
\end{abstract}

Abstrak: Tujuan penelitian ini adalah untuk meningkatkan aktivitas dan hasil belajar siswa menggunakan model pembelajaran berbasis masalah berbantuan media power point pada siswa Kelas III SDN Pandean Lamper 02 Semarang. Metode penelitian yang digunakan adalah penelitian tindakan kelas terdiri dari 3 Siklus dengan 4 tahapan yaitu perencanaan, tindakan, observasi, dan refleksi. Subjek penelitian ini adalah siswa kelas III dengan jumlah 30 orang. Teknik pengumpulan data yang digunakan adalah observasi, wawancara, tes, dan dokumentasi, sedangkan teknik analisis data menggunakan analisis deskriptif. Hasil penelitian menunjukkan bahwa rata-rata persentase aktivitas siswa secara klasikal mengalami peningkatan. Pada Pra Siklus sebelum perlakuan sebesar $65 \%$, pada siklus I sebesar $70 \%$, pada siklus II sebesar $74 \%$ sedangkan pada siklus III $87 \%$. Sedangkan persentase ketuntasan hasil belajar pada pra siklus sebesar $37 \%$, siklus I diperoleh 57\%, pada siklus II 73\%, sedangkan pada siklus III 90\%. Berdasarkan hasil penelitian yang telah dilakukan dapat disimpulkan bahwa pembelajaran pada Tema 8 menggunakan model pembelajaran berbasis masalah berbantuan media power point dapat meningkatkam aktivitas dan hasil belajar siswa.

How to Cite: Mandasari, N. (2021). Penerapan Model Pembelajaran Berbasis Masalah Berbantuan Media Power Point untuk Meningkatkan Aktivitas dan Hasil Belajar Siswa di SDN Pandean Lamper 02 Semarang. Jurnal Paedagogy, 8(3), 328-337. doi:https://doi.org/10.33394/jp.v8i3.3886

https://doi.org/10.33394/jp.v8i3.3886

This is an open-access article under the CC-BY-SA License.

\section{Pendahuluan}

Mutu pendidikan yang tinggi diperlukan untuk menciptakan sumber daya manusia yang cerdas dan profesional dalam era Globalisasi (Santyasa, 2014). Di satu sisi, pendidikan sangat bergantung kepada kompetensi guru, terlebih pada kondisi saat ini dimana pembelajaran lebih ditekankan pada penggunaan aplikasi media dan teknologi. Salah satu

\section{Sejarah Artikel}

Direvisi: $15-06-2021$

Disetujui: 21-06-2021

Diterbitkan: 07-07-2021

Kata Kunci:

Pembelajaran Berbasis

Masalah, Media PPT,

Aktivitas, Hasil Belajar. 
kompetensi guru yang harus dikembangkan adalah kompetensi pedagogik, dimana guru harus bisa mengelola pembelajaran di kelas. Pembelajaran dikatakan berhasil apabila dilakukan secara bermakna, siswa aktif dalam pembelajaran, adanya motivasi untuk menumbuhkan keaktifan siswa dalam pembelajaran, nilai siswa baik dan tuntas sesuai dengan kriteria ketuntasan minimal (KKM), siswa menjadi reatif dan kritis, serta tumbuh karakter yang baik pada diri siswa (Roshida, 2020; Nirta, 2019; Asni, 2017).

Permasalahan yang ditemukan di kelas III pada SDN Pandean Lamper 02 Semarang melalui observasi bahwa aktivitas belajar siswa rendah dengan $65 \%$ sehingga mempengaruhi hasil belajar kognitif pembelajaran Tematik persentase ketuntasan sebesar 37\% pada tema 8 Praja Muda Karana, guru hanya menggunakan media buku Tema, guru dalam menggunakan metode ceramah tanpa adanya feed back dari siswa, oleh karena itu siswa hanya mendengarkan tanpa adanya usaha untuk menggali pengetahuannya sendiri dan tidak belajar untuk berfikir kritis dalam menghadapi suatu permasalahan karena materi yang diterima dalam proses pembelajaran hafalan tanpa adanya makna yang berarti dari suatu proses yang telah mereka lakukan. Hal ini sesuai dengan Pembelajaran berbasis masalah yang rangkaian aktifitas pembelajaran menekankan pada proses penyelesaian masalah yang dihadapi secara ilmiah (Sanjaya, 2008; Akbar, 2019). Model PBL menurut Ibrahim dan Nur dalam Trianto (2007) terdapat lima tahap utama, antara lain yaitu: 1) Orientasi siswa kepada masalah, 2) Mengorganisasi siswa untuk belajar yang telah dirumuskan, 3) Membimbing penyelidikan Individual maupun kelompok, 4) Mengembangkan dan Menyajikan hasil karya, 5) Menganalisis dan mengevaluasi Proses pemecahan masalah. Selain itu, Hamdani (2011) juga mengatakan media yang baik akan mengaktifkan siswa dalam memberikan tanggapan, umpan balik, dan mendorong siswa untuk melakukan praktik-praktik yang benar. Jadi pada dasarnya, untuk menciptakan pembelajaran yang efektif dan menyenangkan memerlukan sebuah media, salah satunya media powerpoint dengan keunggulan pesan informasi Visual mudah dipahami peserta didik sehingga lebih merangsang anak mengetahui lebih jauh informasi tentang bahan ajar yang tersaji sehingga dapat memenuhi Adapun indikator untuk mengamati aktivitas belajar siswa selama proses pembelajaran yaitu: 1) Aktivitas bertanya, 2) Aktivitas dalam kerja kelompok, 3) Aktivitas menjawab pertanyaan diskusi, 4) Siswa mempresentasikan hasil kerja diskusi di depan kelas.

Pembelajaran dengan menggunakan model PBL berbantuan media power point hal ini didukung dengan Penelitian terdahulu dari Putri Avri Yustita (2020) dengan judul "Meningkatkan Aktivitas dan Hasil Belajar Siswa Materi Pekerjaan Orangtuaku Menggunakan Model Pembelajaran PBL Berbantuan Power Point Pada Siswa SDN Pengabean 01 Brebes". Dari hasil penelitian tersebut menunjukkan bahwa aktivitas semula $6,25 \%$ meningkat menjadi $62,5 \%$, sedangkan siswa yang kurang aktif menurun yang semula $62,5 \%$ menjadi 6,25\%. Sedangkan hasil belajar pada kondisi awal terdapat siswa sebanyak 12 orang yang mendapatkan nilai dibawah KKM, selanjutnya pada siklus II siswa yang mendapatkan nilai kurang dari 70 sebanyak 1 siswa $(6,25 \%)$. Pembelajaran dinyatakan presentase ketuntasan $(93.75 \%)$. Adapun tujuan penelitian ini adalah untuk meningkatkan aktivitas dan hasil belajar siswa menggunakan model pembelajaran berbasis masalah berbantuan media power point pada siswa Kelas III SDN Pandean Lamper 02 Semarang.

\section{Metode Penelitian}

Metode penelitian ini adalah Penelitian Tindakan Kelas (PTK), Prosedur Penelitian ini menggunakan dua siklus setiap siklus terdiri dari dua pertemuan yang masing-masing terdiri atas empat kegiatan yang dilakukan dalam siklus berulang. Empat kegiatan utama yang 
ada pada setiap siklus, yaitu 1) perencanaan, 2). Tindakan 3). pengamatan, 4). Refleksi (Arikunto, 2013).

Penelitian ini dilaksanakan di SDN Pandean Lamper 02 Semarang Subyek penelitian adalah siswa kelas III sebanyak 30 orang siswa dimana proses pembelajarannya dilakukan melalui aplikasi Google Meet. Penelitian dilaksanakam pada semester 2 Tahun Ajaran 2020/2021 pada Tema 8 Praja Muda Karana pada Subtema 1 Aku Anak Pramuka Pembelajaran 1 dan 2, Subtema 2 Aku Anak Mandiri Pembelajaran 1 dan 2, dan Subtema 3 Aku Anak Petualang Pembelajaran 1 dan 2. Pengambilan data dilakukan dengan teknik tes dan non tes. Teknik tes meliputi ulangan pada akhir siklus I, akhir siklus II dan Siklus III sedangkan non tes meliputi observasi aktivitas siswa, observasi terhadap pembelajaran guru serta angket tanggapan observer terhadap pembelajara guru. Menurut Arikunto (2013) observasi adalah suatu teknik yang dilakukan dengan cara mengadakan pengamatan secara teliti serta mencatat secara sistematis".

Indikator keberhasilan (tolok ukur) penelitian tindakan kelas ini adalah apabila aktivitas belajar siswa dikatakan meningkat apabila dari rata-rata persentase diperoleh minimal $75 \%$ pada tiap indikator aktivitas tersebut meliputi : 1) Aktivitas bertanya, 2) Aktivitas dalam kerja kelompok, 3) Aktivitas menjawab pertanyaan diskusi, 4)Siswa mempresentasikan hasil kerja diskusi di depan kelas. Indikator keberhasilan hasil belajar siswa memperoleh nilai KKM 70 dan persentase ketuntasan memperoleh $75 \%$. Teknik analisis data yang digunakan dalam penelitian ini adalah teknik analisis deskriptif dengan menggunakan presentase yaitu membandingkan aktivitas dan hasil belajar siswa antara Siklus 1, Siklus II, Siklus III.

\section{Hasil Penelitian dan Pembahasan Deskripsi Siklus 1}

Pada tahap perencanaan pembelajaran siklus I, perencanaan dibuat berdasarkan kelemahan-kelemahan yang teridentifikasi pada tahap pra siklus untuk dicari pemecahannya. Kegiatan pelaksanaan pembelajaran terdiri dari pendahuluan, isi dan penutup. 3 Tahapan pembelajaran ini sesuai dengan penelitian yang dilakukan oleh (Rahmadani \& Anugraheni, 2017). Adapun tindakan perbaikan yang akan dilakukan melalui pembelajaran menggunakan model PBL berbantuan media Power Point yang dilaksanakan melalui empat langkah yaitu: 1) Orientasi siswa kepada masalah, 2 Mengorganisasi siswa untuk belajar, 3) Membimbing penyelidikan Individual maupun kelompok, 4) Mengembangkan dan Menyajikan hasil karya yaitu membantu siswa dalam merencanakan dan menyiapkan karya, 5) Menganalisis dan mengevaluasi Proses pemecahan masalah. Hasil pengolahan aktivitas belajar siklus 1 secara rinci disajikan dalam tabel sebagai berikut:

Tabel 1. Skor Aktivitas Belajar Berdasarkan Observasi Siklus I

\begin{tabular}{|c|l|c|}
\hline No. & \multicolumn{1}{|c|}{ Indikator } & Skor \\
\hline 1. & Aktivitas bertanya & $\mathbf{6 6 \%}$ \\
\hline 2. & Aktivitas dalam kerja kelompok & $\mathbf{6 9 \%}$ \\
\hline 3. & Aktivitas menjawab pertanyaan diskusi & $\mathbf{7 7 \%}$ \\
\hline 4. & Aktivitas mempresentasikan hasil kerja diskusi di depan kelas & $\mathbf{6 8 \%}$ \\
\hline \multicolumn{2}{|r|}{ Skor Rata-rata } & $\mathbf{7 0 \%}$ \\
\hline
\end{tabular}

Pedoman kriteria keaktifan peserta didik pada pembelajaran menurut Arikunto (2009) adalah sebagai berikut: 
Tabel 2. Pedoman kriteria aktivitas peserta didik

\begin{tabular}{|c|c|}
\hline Capaian & Kriteria \\
\hline $75 \%-100 \%$ & Tinggi \\
\hline $50 \%-74,99 \%$ & Sedang \\
\hline $25 \%-49,99 \%$ & Rendah \\
\hline $0 \%-24,99 \%$ & Sangat rendah \\
\hline
\end{tabular}

Berdasarkan hasil observasi aktivitas belajar di atas diketahui terdapat tiga indikator yang belum memenuhi kriteria minimal rata-rata yaitu sebesar $70 \%$ dengan kriteria sedang. Indikator tersebut adalah aktivitsas "bertanya", aktivitas dalam "kerja kelompok", aktivitas "mempresentasikan" hasil diskusi. Hal tersebut terlihat pada saat berdiskusi peserta didik takut untuk bertanya sehingga dalam Indikator aktivitas dalam bertanya memiliki skor indikator paling rendah sebesar $66 \%$. Maka dari itu, indikator yang belum mencapai rata-rata minimal $75 \%$ selanjutnya akan digunakan sebagai bahan refleksi dan diperbaiki pada siklus II. Pada akhir pembelajaran dilakukan tes evaluasi siklus I terdiri dari 10 soal yang dishare melalui WA Group kemudian dikirimkan melalui link google formulir. Berikut hasil rekapitulasi dari nilai peserta didik pada tes evaluasi siklus I dengan materi pada Tema 8 Praja Muda Karana.

Tabel 3. Data Hasil Belajar Peserta Didik Siklus I

\begin{tabular}{|c|c|}
\hline Hasil Penilaian & Nilai \\
\hline Nilai Rata-rata & 68 \\
\hline Nilai Tertinggi & 80 \\
\hline Nilai Terendah & 45 \\
\hline Jumlah Siswa yang Tuntas & 17 \\
\hline Jumlah Siswa yang Tidak Tuntas & 13 \\
\hline Presentase Ketuntasan & $\mathbf{5 7 \%}$ \\
\hline
\end{tabular}

Berdasarkan data pada tabel di atas, dapat dijelaskan bahwa hasil belajar peserta didik pada kelas III SDN Pandean Lamper 02 Semarang pada siklus I menunjukan nilai rata-rata 68 dari 30 siswa. Dengan persentase ketuntasan sebesar 57\%. Hal ini diketahui dari sebelum diberikan perlakuan pada pra siklus mengalami peningkatan namun belum dikatakan TUNTAS karena masih dibawah KKM yaitu 70. Nilai tertinggi yaitu 80 dan Nilai terendah adalah 45.

\section{Deskripsi Siklus II}

Pada tahap perencanaan pembelajaran siklus II, perencanaan dibuat berdasarkan kelemahan-kelemahan yang teridentifikasi pada tahap pra siklus untuk dicari pemecahannya. Kegiatan pelaksanaan pembelajaran terdiri dari pendahuluan, isi dan penutup. 3 Tahapan pembelajaran ini sesuai dengan penelitian yang dilakukan oleh (Rahmadani \& Anugraheni, 2017). Adapun tindakan perbaikan yang akan dilakukan melalui pembelajaran menggunakan model PBL berbantuan media Power Point yang dilaksanakan melalui empat langkah yaitu: 1) Orientasi siswa kepada masalah, 2) Mengorganisasi siswa untuk belajar, 3) Membimbing penyelidikan Individual maupun kelompok, 4) Mengembangkan dan Menyajikan hasil karya yaitu membantu siswa dalam merencanakan dan menyiapkan karya, 5) Menganalisis dan mengevaluasi Proses pemecahan masalah. Hasil pengolahan aktivitas belajar siklus II secara rinci disajikan dalam tabel berikut ini. 
Tabel 4. Skor Aktivitas Belajar Berdasarkan Observasi Siklus II

\begin{tabular}{|c|l|c|}
\hline No. & \multicolumn{1}{|c|}{ Indikator } & Skor \\
\hline 1. & Aktivitas bertanya & $\mathbf{7 5 \%}$ \\
\hline 2. & Aktivitas dalam kerja kelompok & $\mathbf{7 6 \%}$ \\
\hline 3. & Aktivitas menjawab pertanyaan diskusi & $\mathbf{7 5 \%}$ \\
\hline 4. & Aktivitas mempresentasikan hasil kerja diskusi di depan kelas & $\mathbf{7 3 \%}$ \\
\hline \multicolumn{2}{|r}{ Skor Rata-rata } & $\mathbf{7 4 \%}$ \\
\hline
\end{tabular}

Berdasarkan hasil observasi aktivitas belajar peserta didik tiga indicator terpenuhi yaitu aktivitas bertanya dengan skor $75 \%$, aktivitas dalam kelompok dengan skor $75 \%$, aktivitas menjawab pertanyaan diskusi dengan skor $76 \%$, namun ada satu indikator yang belum terpenuhi yaitu aktivitas mempresentasikan hasil kerja diskusi di depan kelas dengan skor 73\%. Setelah dirata-rata skor dari empat indicator tersebut memperoleh persentase sebesar 74\% dari seluruh jumlah peserta didik, sehingga belum mencapai kriteria yang diinginkan, namun sudah terdapat peningkatan pada tiap indikator. Setelah pembelajaran pada siklus II selesai, dilakukan tes evaluasi yang terdiri dari 10 soal yang dishare melalui WA Group kemudian dikirimkan melalui link google form. Berikut hasil rekapitulasi dari nilai peserta didik pada tes evaluasi siklus II dengan materi pada tema 8 Subtema 2 Aku Anak Mandiri.

Tabel 5. Data Hasil Belajar Peserta Didik Siklus II

\begin{tabular}{|c|c|}
\hline Hasil Penilaian & Nilai \\
\hline Nilai Rata-rata & 74 \\
\hline Nilai Tertinggi & 100 \\
\hline Nilai Terendah & 50 \\
\hline Jumlah Siswa yang Tuntas & 22 \\
\hline Jumlah Siswa yang Tidak Tuntas & 8 \\
\hline Presentase Ketuntasan & $\mathbf{7 3 \%}$ \\
\hline
\end{tabular}

Berdasarkan data pada table di atas, dapat dijelaskan bahwa hasil belajar peserta didik pada kelas III SDN Pandean Lamper 02 Semarang pada siklus II menunjukan nilai rata-rata 74 dari 30 siswa, dengan persentase $73 \%$. Terdapat 22 siswa TUNTAS dan 8 Siswa TIDAK TUNTAS. Nilai tertinggi yaitu 100 dan Nilai terendah adalah 50. Setelah dirata-rata skor dari empat indikator tersebut memperoleh persentase sebesar $74 \%$ dari seluruh jumlah peserta didik, sehingga belum mencapai kriteria yang diinginkan, namun sudah terdapat peningkatan pada tiap indicator dan hasil belajar masing-masing peserta didik sudah memenuhi KKM, tetapi belum mencapai kriteria keberhasilan yang ditentukan peneliti yaitu kriteria keberhasilan 75\%. Dengan 22 siswa TUNTAS dan 8 TIDAK TUNTAS. Perbaikan yang akan dilakukan adalah menekankan membimbing jalannya diskusi pada saat proses pembelajaran berlangsung sesuai dengan tujuan pembelajaran yang diharapkan agar peserta didik mampu mempresentasikan didepan kelas dan mengeluarkan pendapatnya. Peneliti akan menyampaikan teknis diskusi agar suasana tetap kondusif.

\section{Deskripsi Siklus III}

Pada tahap perencanaan pembelajaran siklus III, perencanaan dibuat berdasarkan kelemahan-kelemahan yang teridentifikasi pada tahap pra siklus untuk dicari pemecahannya. Kegiatan pelaksanaan pembelajaran terdiri dari pendahuluan, isi dan penutup. 3 Tahapan pembelajaran ini sesuai dengan penelitian yang dilakukan oleh (Rahmadani \& Anugraheni, 2017). Adapun tindakan perbaikan yang akan dilakukan melalui pembelajaran menggunakan model PBL berbantuan media Power Point yang dilaksanakan melalui empat langkah yaitu:1) 
Orientasi siswa kepada masalah, 2) Mengorganisasi siswa untuk belajar, 3) Membimbing penyelidikan Individual maupun kelompok, 4) Mengembangkan dan Menyajikan hasil karya yaitu membantu siswa dalam merencanakan dan menyiapkan karya, 5) Menganalisis dan mengevaluasi Proses pemecahan masalah. Hasil pengolahan aktivitas belajar siklus III secara rinci disajikan dalam tabel sebagai berikut:

Tabel 6. Skor Aktivitas Belajar Berdasarkan Observasi Siklus III.

\begin{tabular}{|c|l|c|}
\hline No. & \multicolumn{1}{|c|}{ Indikator } & Skor \\
\hline 1. & Aktivitas bertanya & $\mathbf{8 6 \%}$ \\
\hline 2. & Aktivitas dalam kerja kelompok & $\mathbf{8 7 \%}$ \\
\hline 3. & Aktivitas menjawab pertanyaan diskusi & $\mathbf{9 1 \%}$ \\
\hline 4. & Aktivitas mempresentasikan hasil kerja diskusi di depan kelas & $\mathbf{8 5 \%}$ \\
\hline \multicolumn{2}{|r|}{ Skor Rata-rata } & $\mathbf{8 7 \%}$ \\
\hline
\end{tabular}

Berdasarkan hasil observasi aktivitas belajar peserta didik seluruh indikator sudah mencapai kriteria minimal yaitu sebesar $75 \%$. Jika dirata-rata skornya mencapai $87 \%$ dan telah melebihi kriteria minimal, yang artinya setiap indikator mengalami peningkatan. Setelah pembelajaran pada siklus III selesai, dilakukan tes evaluasi yang terdiri dari 10 soal yang dishare melalui WA Group kemudian dikirimkan melalui link google formulir. Berikut hasil rekapitulasi dari nilai peserta didik pada tes evaluasi siklus III dengan materi pada tema 8 Praja Muda Karana Subtema 3 Aku Anak Petualang

Tabel 7. Data Hasil Belajar Peserta Didik Siklus III

\begin{tabular}{|c|c|}
\hline Hasil Penilaian & Nilai \\
\hline Nilai Rata-rata & 87 \\
\hline Nilai Tertinggi & 100 \\
\hline Nilai Terendah & 60 \\
\hline Jumlah Siswa yang Tuntas & 27 \\
\hline Jumlah Siswa yang Tidak Tuntas & 3 \\
\hline Presentase Ketuntasan & $\mathbf{9 0 \%}$ \\
\hline
\end{tabular}

Berdasarkan data pada table di atas, dapat dijelaskan bahwa hasil belajar peserta didik pada kelas III SDN Pandean Lamper 02 Semarang pada siklus III menunjukan nilai rata-rata 87 dari 30 siswa. Sebanyak 90\% siswa TUNTAS, sedangkan terdapat 10\% siswa yang BELUM TUNTAS karena masih dibawah KKM yaitu 70. Nilai tertinggi yaitu 100 dan Nilai terendah adalah 60. Berdasarkan hasil pada siklus III terdapat adanya peningkatan Aktivitas Belajar peserta didik yang ditunjukan dengan peningkatan skor pada indikator yang ditetapkan. Refleksi perbaikan dari siklus I sampai siklus III yang berhubungan dengan kegiatan kelompok berjalan dengan baik dimana adanya peningkatan peran siswa dalam kegiatan kelompok yaitu aktivitas bertanya, aktivitas dalam kerja kelompok, aktivitas menjawab pertanyaan, dan aktivitas mempresentasikan hasil kerja.

Penelitian penerapan model Problem Based Learning menggunakan power point ini memiliki tujuan yaitu untuk mengetahui peningkatan aktivitas belajar dan hasil belajar peserta didik. Berdasarkan analisis penelitian diketahui bahwa terdapat peningkatan Aktivitas Belajar peserta didik kelas III SDN Pandean Lamper 02 Semarang. Hal ini dapat terlihat dari adanya peningkatan yang mencerminkan aktivitas belajar yang dilakukan peserta didik selama proses berlangsung, kegiatan yang dilakukan peserta didik telah memenuhi kriteria yang ditetapkan dalam indikator-indikator tentang aktivitas belajar peserta didik yang menunjukkan peningkatan pada saat Prasiklus ke Siklus I, dari Siklus I ke Siklus II, dan dari 
Siklus II ke Siklus III. Peningkatan Aktivitas Belajar peserta didik yang terjadi dalam kegiatan pembelajaran terlihat sebagai berikut:

Tabel 8. Perbandingan Skor Aktivitas Belajar Peserta Didik

\begin{tabular}{|l|c|c|c|c|}
\hline \multirow{2}{*}{\multicolumn{1}{|c|}{ Indikator }} & \multicolumn{4}{c|}{ Skor } \\
\cline { 2 - 5 } & $\begin{array}{c}\text { Pra } \\
\text { siklus }\end{array}$ & Siklus I & Siklus II & Siklus III \\
\hline Aktivitas bertanya & $66 \%$ & $66 \%$ & $75 \%$ & $86 \%$ \\
\hline Aktivitas dalam kerja kelompok & $60 \%$ & $69 \%$ & $76 \%$ & $87 \%$ \\
\hline Aktivitas menjawab pertanyaan diskusi & $69 \%$ & $77 \%$ & $75 \%$ & $90 \%$ \\
\hline $\begin{array}{l}\text { Aktivitas mempresentasikan hasil kerja } \\
\text { diskusi di depan kelas }\end{array}$ & $65 \%$ & $68 \%$ & $73 \%$ & $85 \%$ \\
\hline Skor Rata-rata & $\mathbf{6 5 \%}$ & $\mathbf{7 0 \%}$ & $\mathbf{7 4 \%}$ & $\mathbf{8 7 \%}$ \\
\hline
\end{tabular}

Berdasarkan data di atas terlihat adanya peningkatan aktivitas belajar peserta didik kelas III SDN Pandean Lamper 02 Semarang dengan penerapan model pembelajaran Problem Based Learning menggunakan power point. Berikut data yang dapat dilihat berdasarkan grafik:

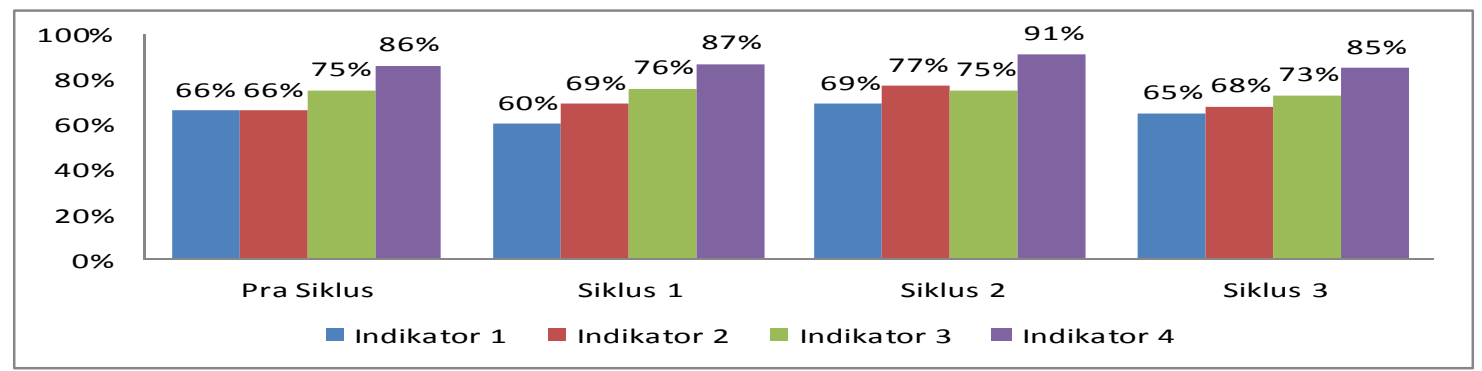

Gambar 1. Diagram Aktivitas Belajar Peserta Didik

Keterangan:

Indikator 1 : Aktivitas bertanya

Indikator 2 : Aktivitas dalam kerja kelompok

Indikator 3 : Aktivitas menjawab pertanyaan diskusi

Indikator 4: Aktivitas mempresentasikan hasil kerja diskusi di depan kelas

Berdasarkan data diagram diatas terlihat bahwa terjadi peningkatan skor Aktivitas Belajar peserta didik dari pra siklus ke siklus I sebesar 5\%, Siklus I ke Siklus II 4\%, sedangkan siklus II ke siklus III sebesar 5\% dan siklus II ke siklus III sebesar 13\%. Pada Pra siklus Indikator capaian aktivitas belajar sebesar persentase $66 \%$ pada indicator aktivitsas "bertanya", aktivitas dalam "kerja kelompok" memperoleh nilai 60,83\%, aktivitas menjawab pertanyaan diskusi mendapatkan 69\%, sedangkan aktivitas "mempresentasikan" hasil diskusi memperoleh $65 \%$. Hasil tersebut belum memenuhi kriteria minimal rata-rata aktivitas belajar sebesar 75\%, sehingga di Hal tersebut akan diberikan model Problem Based Learning menggunakan media powerpoint untuk mengatasi masalah rendahnya aktivitas dan hasil belajar peserta didik. Pada siklus I diperoleh hasil aktivitas belajar pada saat berdiskusi peserta didik takut untuk bertanya sehingga dalam Indikator aktivitas dalam bertanya memiliki skor indikator paling rendah sebesar 66\%, aktivitas dalam "kerja kelompok" memperoleh nilai $69 \%$, aktivitas menjawab pertanyaan diskusi mendapatkan $77 \%$, sedangkan aktivitas "mempresentasikan" hasil diskusi memperoleh $68 \%$ dengan rata-rata $70 \%$. Berdasarkan hasil observasi aktivitas belajar di atas diketahui terdapat tiga indikator yang belum memenuhi kriteria minimal aktivitas belajar sebesar $75 \%$ untuk itu menjadi bahan refleksi untuk dierbaiki pada siklus II Idengan diperoleh persentase sebesar dari indicator 
aktivitsas "bertanya" 75\%, aktivitas dalam "kerja kelompok"76\%, aktivitas menjawab pertanyaan $75 \%$, aktivitas "mempresentasikan" hasil diskusi $73 \%$. Sehingga mendapatkan rata-rata $74 \%$. Masih ada satu indikator mempresentasikan hasil diskusi yang belum memenuhi kriteria ketuntasan minimal aktivitas belajar hal ini terlihat dengan peserta didik masih belum berani tampil dan membacakan hasil diskusi, sehinnga dijadikan refleksi untuk diperbaiki pada siklus ke III. Pada siklus III diperoleh hasil dari Indikator aktivitas dalam bertanya memiliki skor $86 \%$, \%, aktivitas dalam "kerja kelompok" $87 \%$, aktivitas menjawab pertanyaan $91 \%$, aktivitas "mempresentasikan" hasil diskusi $85 \%$. Pada siklus ke III sudah Nampak seluruh indicator mencapai kriteria minimal aktivitas belajar sebesar $75 \%$ dan mendapatkan rata-rata sebesar $87 \%$.

Berdasarkan hasil penelitian yang sudah dilakukan, menunjukan bahwa penerapan model pembelajaran problem based Learning menggunakan powerpoint di kelas III SDN Pandean Lamper 02 Semarang dapat meningkatkan hasil belajar peserta didik pada tema 8 Praja Muda Karana. Hal tersebut dapat dilihat pada tes evaluasi mandiri yang dilakukan setelah selesai pembelajaran pada pra siklus, siklus I, siklus II dan siklus III. Berikut tabel perbandingan hasil tes evaluasi mandiri peserta didik:

Tabel 8. Capaian Hasil Belajar Peserta Didik

\begin{tabular}{|c|c|c|c|c|}
\hline Capaian & Pra Siklus & Siklus I & Siklus II & Siklus III \\
\hline Rata-rata & 61 & 68 & 74 & 87 \\
\hline Nilai Tertinggi & 80 & 80 & 100 & 100 \\
\hline Nilai Terendah & 40 & 45 & 50 & 60 \\
\hline Jumlah Nilai $>\mathbf{7 0}$ & 11 & 17 & 22 & 27 \\
\hline Prosentase ketuntasan & $\mathbf{3 7 \%}$ & $\mathbf{5 7 \%}$ & $\mathbf{7 3 \%}$ & $\mathbf{9 0 \%}$ \\
\hline
\end{tabular}

Berdasarkan data di atas terlihat adanya peningkatan hasil belajar peserta didik kelas III SDN Pandean Lamper 02 Semarang dengan penerapan model pembelajaran Problem Based Learning menggunakan power point. Berikut data yang dapat dilihat berdasarkan grafik:

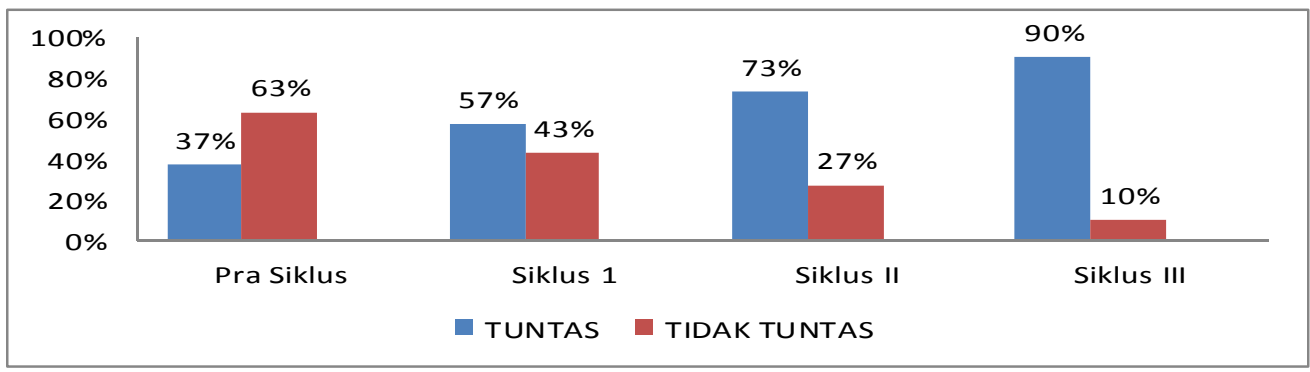

Gambar 2. Diagram Persentase Hasil Belajar Peserta Didik

Perolehan persentase ketuntasan hasil belajar di pra siklus, siklus I, siklus II belum mencapai kriteria keberhasilan yang telah direncanakan, yaitu 37\% pada pra siklus, siklus I 57\%, dan Siklus II diperoleh hasil 73\% dari kriteria keberhasilan 75\%. Meskipun demikian, secara keseluruhan hasil persentase ketuntasan hasil belajar setelah diterapkannya model pembelajaran problem based learning menggunakan powerpoint sudah berhasil mengalami peningkatan mulai dari siklus I ke siklus II. Siklus III diperoleh hasil $90 \%$ sehingga telah mencapai kriteria minimal sebesar 75\%. Berdasarkan hasil belajar peserta didik sebelum diterapkannya pembelajaran problem based learning pada siklus I, siklus II dan siklus III mengalami peningkatan. Hasil belajar peserta didik siklus I mengalami peningkatan yang lebih baik di siklus II, dan siklus II mengalami peningkatan dari siklus I, dan pada siklus III mengalami ketuntasan minimal yang diharapkan yaitu 90\%. Selain itu keberhasilan 
penggunaan model Problem Based Learning menggunakan media power point dibuktikan juga melalui diagram rata-rata pencapaian nilai peserta didik sebagai berikut:

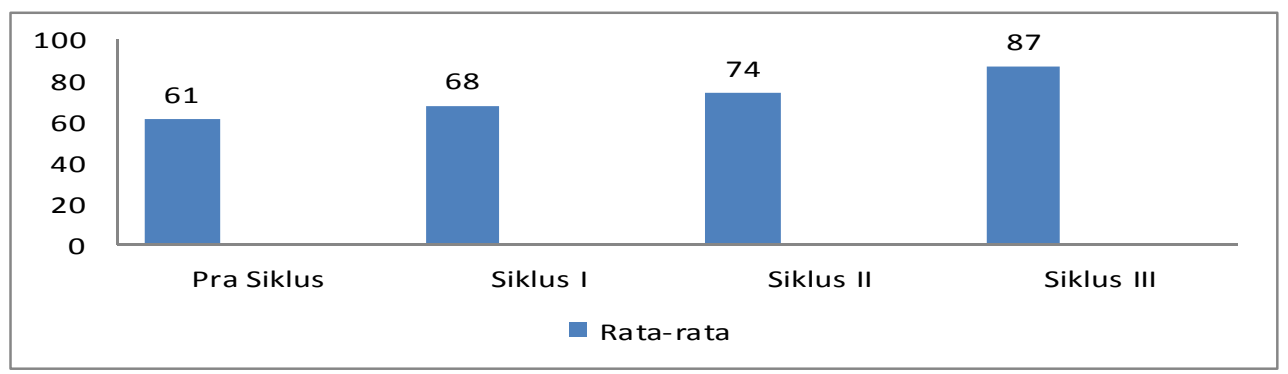

Diagram 3. Diagram Rata-rata Hasil belajar Peserta didik

Berdasarkan diagram diatas, diperoleh nilai rata-rata dari setiap siklus mengalami peningkatan, dari pra siklus diperoleh rata-rata sebesar 61, pada siklus I diperoleh rata-rata 68, siklus II diperoleh rata-rata 74, sedangkan di siklus ke III diperoleh rata-rata 87. Peningkatan tersebut terjadi karena beberapa faktor seperti proses adaptasi, suasana atau keadaan siswa, bimbingan diskusi dan materi setiap siklus berbeda. Pada siklus I, peserta didik secara keseluruhan belum bisa beradaptasi dengan problem based learning Masih terlihat beberapa peserta didik pada saat berdiskusi fokusnya tidak pada materi, dan juga belum mempersiapkan materi dengan baik. Pada siklus II, peserta didik sudah mulai beradaptasi dengan model problem based learning, tetapi diskusi belum berjalan dengan baik karena ada murid yang mendominasi. Pada Siklus III peserta didik sudah mengetahui hal apa yang akan dilakukan dan juga sudah mengerti secara teknis problem based learning dan sebelum pembelajaran peserta didik sudah benar-benar menyiapkan materi yang akan dipelajari serta lebih aktif untuk bertanya ketika tidak memahami materi yang telah didiskusikan.

\section{Kesimpulan}

Berdasarkan hasil penelitian ini dapat disimpulkan bahwa penerapan model PBL berbantuan media Power Point dapat meningkatkan aktivitas belajar kelas III Tema 8 peningkatan dapat terlihat pada pertambahan pencapaian indikator aktivitas belajar peserta didik pada masingmasing siklusnya. Dengan menggunakan observasi terhadap hasil aktivitas belajar peserta didik pada pra siklus diperoleh skor 65\%, siklus I naik 5\% diperoleh skor 70\%, pada siklus II naik $4 \%$ diperoleh skor $74 \%$ kemudian pada siklus III mengalami peningkatan sebesar $13 \%$ yang menjadi 87\%. Penerapan model PBL berbantuan media Power Point dapat meningkatkan hasil belajar kelas III Tema 8 Hal tersebut dapat dilihat dari adanya peningkatan persentase ketuntasan hasil belajar siswa dengan batas KKM yaitu 70. Sebelum diterapkannya model pembelajaran problem based learning adalah $37 \%$, kemudian pada siklus I 57\%, Siklus II meningkat menjadi73\%, dan pada siklus III meningkatkan hingga $90 \%$.

\section{Saran}

Saran yang disampaikan berdasarkan hasil penelitian ini adalah Guru perlu lebih mematangkan persiapan untuk menerapkan pembelajaran problem based learning karena banyak perlengkapan dan beberapa teknis yang memerlukan panduan ketika belum terbiasa model tersebut. Selain itu, bagi peserta didik agar lebih menyiapkan lagi untuk setiap pembelajaran tidak hanya pada saat ada penelitian. Bagi peneliti lainnya dalam melakukan observasi harus lebih detail agar sesuai dengan apa yang akan dilakukan dan diteliti. 


\section{Daftar Pustaka}

Akbar, A. (2019). Implementasi Model Pembelajaran Berbasis Masalah untuk Meningkatkan Hasil Belajar Siswa pada Mata Pelajaran PKn di SMA Negeri 1 Batukliang Utara. Jurnal Kependidikan: Jurnal Hasil Penelitian dan Kajian Kepustakaan di Bidang Pendidikan, Pengajaran dan Pembelajaran, 5(1), 1-7. doi:https://doi.org/10.33394/jk.v5i1.1386

Arikunto, Suharsimi. (2013). Prosedur Penelitian : Suatu Pendekatan Praktik, Edisi Revisi VI, Jakarta : PT Rineka Cipta.

Asni, H. (2017). Upaya Meningkatkan Aktivitas dan Hasil Belajar Peserta Didik Melalui Penerapan Pendekatan Cooperative Learning Tipe Jigsaw di Kelas III-A SD Negeri 2 Cakrangeara. Jurnal Kependidikan: Jurnal Hasil Penelitian dan Kajian Kepustakaan di Bidang Pendidikan, Pengajaran dan Pembelajaran, 3(2). doi:https://doi.org/10.33394/jk.v3i2.567

Arsyad, Azhar. (2013). Media Pembelajaran. Jakarta: PT Rajagrafindo Persada.

Avri, Putri Yustita. (2020). Meningkatkan Aktivitas dan Hasil Belajar Siswa Materi Pekerjaan Orangtuaku Menggunakan Model Pembelajaran PBL Berbantuan Power Point Pada Siswa SDN Pengabean 01 Brebes. Yogyakarta:Universitas Akhmad Dahlan.

Hamdani. (2011). Strategi Belajar Mengajar. Bandung: CV Pustaka Setia.

Nirta, I. (2019). Upaya Meningkatkan Aktivitas dan Hasil Belajar Peserta Didik Kelas IV SD Negeri 14 Cakranegara Melalui Penerapan Pendekatan Cooperative Learning Tipe Jigsaw. Jurnal Paedagogy, 6(1), 8-13. doi:https://doi.org/10.33394/jp.v6i1.2524

Putri, Avri Yustitia, Istiandaru, Afit and Sulistiowati, Erna. (2020) MENINGKATKAN AKTIVITAS DAN HASIL BELAJAR SISWA MATERI PEKERJAAN ORANG TUAKU MENGGUNAKAN MODEL PEMBELAJARAN PBL BERBANTUAN POWERPOINT PADA SISWA KELAS IV SD N PENGABEAN 01 BREBES. http://eprints.uad.ac.id/21589/

Rosidha, A. (2020). Peningkatan Aktivitas dan Hasil Belajar Siswa pada Mata Pelajaran Biologi Melalui Model Pembelajaran Make and Match Berbasis Media Karu Pintar. Jurnal Paedagogy, 7(4), 393-401. doi:https://doi.org/10.33394/jp.v7i4.2946

Sanjaya, Wina. (2006). Strategi Pembelajaran. Jakarta : Kencana.

Suarni, G., Rizka, M., \& Zinnurain, Z. (2021). Analisis Pengaruh Penerapan Model Pembelajaran Sains Teknologi Masyarakat Terhadap Hasil Belajar Siswa. Jurnal Paedagogy, 8(1), 31-38. doi:https://doi.org/10.33394/jp.v8i1.3226

Rahmadani, N., \& Anugraheni, I. (2017). Peningkatan Aktivitas Belajar Matematika Melalui Pendekatan Problem Based Learning Bagi Siswa Kelas 4 Sd". Scholaria: Jurnal Pendidikan dan Kebudayaan, 7(3), 241.https://doi.org/10.24246/j.scholaria.2017.v7.i3.p241-250

Santyasa, I W. (2006). Metodologi Penelitian Peningkatan Kualitas Pembelajaran (PPKP) Research for Instructional Improvement (RII). Makalah. Disajikan dalam Pelatihan Para Dosen Universitas Pendidikan Ganesha tentang Penelitian Tindakan Kelas dan Penelitian Untuk Peningkatan Kualitas Pembelajaran Perguruan Tinggi Tanggal 2 November 2006, di Universitas Pendidikan Ganesha

Trianto, (2007). Model-model Pembelajaran Inovatif Berorientasi Konstruktivistik. Jakarta: Prestasi Pustaka Publisher. 